Chicago-Kent College of Law

Scholarly Commons @ IIT Chicago-Kent College of Law

All Faculty Scholarship

Faculty Scholarship

January 2009

\title{
The Paradox of Public Sector Labor Law
}

Martin H. Malin

IIT Chicago-Kent College of Law, mmalin@kentlaw.iit.edu

Follow this and additional works at: https://scholarship.kentlaw.iit.edu/fac_schol

Part of the Labor and Employment Law Commons

\section{Recommended Citation}

Martin H. Malin, The Paradox of Public Sector Labor Law, 84 Ind. L.J. 1369 (2009).

Available at: https://scholarship.kentlaw.iit.edu/fac_schol/383

This Article is brought to you for free and open access by the Faculty Scholarship at Scholarly Commons @ IIT Chicago-Kent College of Law. It has been accepted for inclusion in All Faculty Scholarship by an authorized administrator of Scholarly Commons @ IIT Chicago-Kent College of Law. For more information, please contact jwenger@kentlaw.iit.edu, ebarney@kentlaw.iit.edu. 


\title{
The Paradox of Public Sector Labor Law
}

\author{
MARTIN H. MALIN* \\ INTRODUCTION
}

Over the years, the public sector has become increasingly important in collective bargaining. In 2008 , only $7.6 \%$ of private sector workers were union members and only $8.4 \%$ were represented by unions. ${ }^{1}$ In contrast, $36.8 \%$ of public employees were union members and $40.7 \%$ were represented by unions. ${ }^{2}$ Despite these figures, collective bargaining by public employees remains controversial. Although most jurisdictions have statutes granting collective bargaining rights to at least some public employees, North Carolina and Virginia expressly prohibit public sector collective bargaining by statute. ${ }^{3}$ In recent years, governors in Indiana, Kentucky, and Missouri have revoked executive orders that had given employees of those states collective bargaining rights, ${ }^{4}$ while governors in Arizona and Colorado have issued executive orders providing for collective representation of state executive branch employees. ${ }^{5}$ Regulations by the Department of Homeland Security (DHS) and the Department of Defense sought to severely curtail collective bargaining rights of their employees. The D.C. Circuit struck down the DHS regulations, ${ }^{6}$ but the same court upheld the Department of Defense regulations. ${ }^{7}$

Two of the most powerful arguments against public employee collective bargaining are that it is antidemocratic and that it impedes effective government. At one time these

* Professor of Law and Director, Institute for Law and the Workplace, Chicago-Kent College of Law, Illinois Institute of Technology. This Article has benefited greatly from comments on a prior draft received from Christopher Cameron, Roberto Corrada, Henry Drummonds, Matthew Finkin, Rafael Gely, Sarah Harding, Ann Hodges, Charles Kerchner, Cesar Rosado, Mitchell Rubenstein, Joseph Slater, and Richard Warner. I gratefully acknowledge superb research assistance from Tracy Scholnick Gruber and financial support from the Marshall-Ewell Research Fund at Chicago-Kent.

1. Bureau of Labor Statistics, U.S. Dep'T of Labor, News Release No. 09-0095, UNION MEMBERS IN 2008, at 8 tbl.3 (2009), available at

http://www.bls.gov/news.release/pdf/union2.pdf. The term "union members" is defined as "members of a labor union or an employee association similar to a union." Id. The term "represented by unions" includes "workers who report no union affiliation but whose jobs are covered by a union or an employee association contract," in addition to "union members." Id.

2. Id.

3. N.C. Gen. STAT. ANN. $\S 95-98$ (West 2008); VA. Code ANN. $§ 40.1-57.2$ (2008).

4. See David Bacon, The Midwest Union Rollback, IN THESE TIMES, Feb. 24, 2005, available at $\mathrm{http} / / / \mathrm{www}$.inthesetimes.com/article/1958/the_midwest_union_rollback/; Rebecca Clarren, New Governor Trashes Union Rights of Indiana State Workers, THE NEW STANDARD, Jan. 26, 2005, available at http://newstandardnews.net/content/index.cfm/items/1409.

5. Ariz. Exec. Order No. 2008-30, 14 Ariz. Admin. Reg. 4947 (Dec. 26, 2008); Colo. Exec. Order No. D 02807 (Nov. 2, 2007), available at

http://www.colorado.gov/cs/Satellite?c=Page\&cid=1 199121589584\&pagename=GovRitter\% 2FGOVRLayout (click on the corresponding hyperlink in the table of " $D$ " Orders).

6. Nat'l Treas. Employees Union v. Chertoff, 452 F.3d 839, 867-68 (D.C. Cir. 2006).

7. Am. Fed'n of Gov't Employees v. Gates, 486 F.3d 1316, 1326-27 (D.C. Cir. 2007). 
arguments were invoked to justify prohibiting public employees from joining unions. ${ }^{8}$ Today, the arguments are invoked in some jurisdictions to preclude collective bargaining by public employees. However, even in jurisdictions that recognize public employees' rights to bargain collectively, these concerns are used to narrow the scope of what must be and, in some cases, what may be negotiated. The argument that collective bargaining is antidemocratic is invoked most often by courts in narrowing the scope of what is negotiable. Although the argument that collective bargaining impedes effective government is sometimes advanced by courts when refusing to enforce collective bargaining agreements, the effective government argument is more often used by the legislative and executive branches as a backlash against public employee unions and as justification for further narrowing the scope of negotiability.

In this Article, I contend that the narrowness of what is negotiable which results from concerns with the antidemocratic tendencies of collective bargaining leads to collective bargaining impeding effective government. Specifically, I argue that the law governing negotiability channels unions away from participation in, and hence responsibility for, decisions affecting the risks of the public sector enterprise and restricts the unions to negotiating contract provisions that protect employees from those risks. Unions perform their narrow role very effectively-so effectively that the results can impede effective government. Part I discusses the argument that public sector collective bargaining is antidemocratic. Part II discusses the argument that public sector collective bargaining impedes effective government. Part III presents the paradox of how the narrow scope of bargaining resulting from concerns with the antidemocratic nature of public sector collective bargaining channels the parties' dealings to the point where collective bargaining can impede effective government. Part IV calls upon the jurisdictions to experiment with reforms.

\section{The ARgument that Public Sector Collective Bargaining Is ANTIDEMOCRATIC}

Many years ago, when my children were in elementary school, the municipality in which I resided was facing a significant budget deficit. The village manager's proposals to save money included eliminating the eight paid, part-time school crossing guard positions and substituting parent volunteers. The proposal outraged many parents-including me. Operating through the Parent-Teacher Organization (PTO), we lobbied for the village board to reject the proposal and find another way to close the budget gap. The union that represented the crossing guards also lobbied against the proposal. Although the union's arguments were couched similarly to the PTO's arguments, which focused on the safety of children walking to school, its primary interest was to preserve the jobs of its members.

At the village board meeting where the issue was considered, no individuals, or organized interest groups supported the village manager's proposal. Although the union spoke against the proposal, it demonstrated its political intelligence by largely staying in the background and allowing the PTO to lead the charge by parading

8. See Joseph E. Slater, The Court Does Not Know "What a Labor Union Is": How State Structures and Judicial (Mis)constructions Deformed Public Sector Labor Law, 79 OR. L. REV. 981, 989-1021 (2000). 
parents, teachers, and school administrators before the board, each emphasizing the folly of the proposal. The result was not surprising. The village board voted to table the proposal and refer it to a committee consisting of parents, teachers, school administrators, and a representative of the village manager's office to study ways of reducing the costs of the program. Eventually, the committee recommended turning one intersection staffed by a crossing guard into an all-way stop, eliminating that crossing guard position while retaining the seven other crossing guards. The village board accepted the recommendation, the new stop signs were erected, and the one position was eliminated.

Assume, however, that the union demanded that the village negotiate the proposal to replace the crossing guards with unpaid volunteers or to negotiate the effects of the proposal on the employees. Viewed from a private sector perspective, under the National Labor Relations Act, ${ }^{9}$ the decision to replace the crossing guards with unpaid volunteers turned on labor costs. It represented a decision to replace bargaining unit employees with a cheaper workforce. As such, it was a mandatory subject of bargaining; that is, the employer would be required to negotiate the decision with the union representing the employees. ${ }^{10}$ Even if the decision itself was not a mandatory subject of bargaining, the effects of the decision on the employees whose jobs were to be eliminated would be a mandatory subject. ${ }^{11}$ If the decision itself was bargained, the union's goal would be to change it. If the effects were bargained, the union's goal would be to raise the cost of implementation of the decision to the point where the decision was no longer worth implementing. Depending on the respective state's law, the union's negotiating position could be backed by a lawful threat to strike, ${ }^{12}$ or a threat to compel the employer to arbitrate the issue if negotiations did not produce agreement. $^{13}$

Assume further that there were eight crossing guard positions, but the union knew that three of the eight incumbents would not be returning the following school year. The union might have been willing to agree in bargaining to the elimination of three positions effective with the start of the next school year, particularly if the union could, in exchange, get concessions that did not cost the village any money but were valuable to the union. The village would likely be willing to agree to such a deal, rather than face a potential strike or risk a less favorable result in interest arbitration. Upon announcement of the result, the parents would likely be outraged - not only over the elimination of the three positions, but also over their exclusion from the decisionmaking process. Although the village board would have to ratify the agreement in a public meeting, at which the parents would have the opportunity to voice their displeasure, by that point it would have been a done deal and the parents' voices would have been largely ineffective.

9. 29 U.S.C. $\S \S 151-169(2006)$.

10. See Fibreboard Paper Prods. Corp. v. NLRB, 379 U.S. 203, 209-10 (1964).

11. See First Nat'l Maint. Corp. v. NLRB, 452 U.S. 666, 681-82 (1981).

12. See, e.g., ALASKa STAT. § 23.40 .080 (2008); HAW. REv. STAT. \& 89-12 (2008); 5 ILL. COMP. StAT. ANN. 315/17 (West 2005); 115 ILl. Comp. STAT. ANN. 5/13 (West 2006); MNNN. StAT. ANN. § 179A.18 (West 2006); OHIo Rev. Code ANN. § 4117.03 (LexisNexis 2007).

13. See, e.g., ConN. Gen. STAT. ANN. § 7-473c (West 2008); ConN. GEN. STAT. ANN. § 10$153 \mathrm{f}$ (West 2002); IowA CoDE ANN. $\S 20.22$ (West 2001); ME. REV. STAT. ANN. tit. 26, $\$ 965$ (2007); WIS. STAT. ANN. $\$ 111.70(4)(C)(6)$ (West 2002). 
The contrasting ways in which the crossing guard issue might have been handled illustrate why many regard public sector collective bargaining to be antidemocratic. According to this view, public employees' wages and working conditions raise inherently political issues. Whether the village should employ crossing guards raised serious public policy issues concerning spending priorities and revenue sources. There was no question that the village had to close its budget deficit. There was, however, a serious question over the safety risks posed by the elimination of crossing guards when weighed against the cost of the guards and against other ways which the village could conserve funds or raise additional revenue. More generally, employee salaries and benefits usually comprise the largest portion of public employer budgets and, ultimately, affects spending priorities and tax rates. Subjecting such matters to collective bargaining, the argument goes, provides one interest group-the unionwith an avenue of access to public decision makers that is denied to every other interest group. As Wellington and Winter observed in their classic work, The Unions and the Cities, "[A] full transplant of collective bargaining [from the private sector] ... would, in many cases, institutionalize the power of public employee unions in a way that would leave competing [interest] groups in the political process at a permanent and substantial disadvantage."14

The view that public employee collective bargaining is antidemocratic figures prominently in arguments for eliminating or greatly restricting collective representation of government employees. For example, Professor Robert Summers has argued against enactment or continuation of public employee labor relations acts on the ground that any collective bargaining by public employees inherently diminishes democracy. ${ }^{15}$ The view that collective representation of public employees undermines democracy also figured prominently in the actions of President George W. Bush in dealing with the federal workforce.

During his first month in office, President Bush revoked Executive Order 12,871, which President William Jefferson Clinton issued on October $1,1993 .^{16}$ Executive Order 12,871, among other things, established the National Partnership Council and called for the creation of labor-management partnerships throughout the executive branch. ${ }^{17}$ The goal of the partnerships was to "champion change in Federal Government agencies to transform them into organizations capable of delivering the highest quality services to the American people."18

Because the scope of bargaining under the Federal Service Labor Management Relations Act is so narrow, partnerships became the mechanism by which unions and management handled most significant issues. The Clinton Administration's Office of Personnel Management Director, Janice Lachance, characterized federal sector labor relations as follows: "[P]artnership is the high wire act and collective bargaining is the

14. Harry H. Wellington \& Ralph K. Winter, JR., The Unions and the Cities 30 (1971).

15. Robert S. Summers, Public Sector Collective Bargaining Substantially Diminishes Democracy, Gov'T UNION REV., Winter 1980, at 5, 6.

16. Exec. Order No. 13,203, 3 C.F.R. 761 (2002), reprinted as amended in 5 U.S.C. $\$ 7101$ (Supp. 2001).

17. Exec. Order No. 12,871, 3 C.F.R. 655 (1994), reprinted as amended in 5 U.S.C. $\S 7101$ (1994).

18. Id. 
safety net."19 In 1997, the National Partnership Council reported a trend among partnerships to focus on what the Council characterized as "nontraditional issues," including reorganizations, quality issues, improvements in customer service, reengineering and streamlining work, the impact of new technology, reductions in force, budget and staffing levels, privatization, and procurement. ${ }^{20}$

What the Clinton Administration viewed as good government and good labor relations, the Bush Administration viewed as antidemocratic. As President Bush was preparing to take office, the Heritage Foundation issued a report that called on him to revoke Executive Order 12,871 as his first act involving the management of government. ${ }^{21}$ The report argued that labor-management partnerships were a major impediment to the Bush Administration's ability to implement its political and policy agenda. ${ }^{22}$ The report branded career civil servants as the "permanent government," a segment that must be controlled and limited to using its expertise to implement policies the President and his political appointees set. ${ }^{23}$ It called on the Office of Presidential Personnel to "make appointment decisions based on loyalty first and expertise second, and that the whole governmental apparatus must be managed from this perspective."24

The Heritage Foundation report criticized Executive Order 12,871 for "reduc[ing] the leverage any president can exert to ensure that the agencies accept and faithfully implement his policy agenda. Without the central management tools to encourage and reward constructive behavior, the president's agenda will be subordinated to internal organizational priorities." ${ }^{25}$ Thus, the Heritage Foundation called for a return to a command and control approach to personnel management, with the command and control exercised by political appointees selected for their loyalty to the President rather than their technical expertise.

The Heritage Foundation's concerns that the partnership councils would impede the President's policy agenda were grossly overstated. As developed in Part IV, the partnership councils institutionalized an avenue of employee voice that challenged employees, through their unions, to take responsibility for the efficient operation of their agencies and the craft, artistic, or professional aspects of their work. Final decision-making authority, however, continued to rest with agency managers who were ultimately accountable to elected officials. The Heritage Foundation report essentially called for a federal workforce that was obedient and robotic when government service begs, not for obedience, but for smartness and invention.

Nevertheless, President Bush acted quickly on the Heritage Foundation's recommendations. In revoking Executive Order 12,871, President Bush dissolved the National Partnership Council and directed the heads of all executive agencies to

19. OPM Director Lachance Addresses Future of Federal Workforce, [Jan.-June] Gov't Empl. Rel. Rep. (BNA) No. 1759, at 422 (Apr. 13, 1998).

20. NAT'L P'shIP COUNCIL, Report to the President on Progress IN LaboRMANAGEMENT PARTNERSHIPS 19-20 (1997).

21. George NesterczuK, Donald J. DeVIne \& Robert E. Moffit, The Heritage Found., TAKING CHARGE OF FEDERAL PERSONNEL (2001), available at http://www.heritage.org/Research/GovernmentReform/BG1404.cfm.

22. Id.

23. $I d$.

24. Id. at Lesson No. 4.

25. Id. at Strategy No. 7. 
"promptly move to rescind any orders, rules, regulations, guidelines, or policies implementing or enforcing Executive Order $12871 \ldots$. . ."26

The view that public sector collective bargaining is antidemocratic is not confined to opponents of collective representation of public employees. For example, Professor Clyde Summers, a leading academic proponent of public employee collective representation, accepts the argument as a given. He argues that the antidemocratic nature of collective bargaining is justified because public employees need the special avenue of access that collective bargaining gives them. Without it, he contends, public employees will be outnumbered in the political process by the general electorate who, as consumers of the employees' services, will seek the most service for the lowest price. $^{27}$

The view that public employee collective bargaining is antidemocratic plays a major role in jurisdictions that prohibit such bargaining. For example, enactment of the Virginia statute prohibiting public sector collective bargaining was preceded by the Virginia Supreme Court's decision in Commonwealth v. County Board of Arlington County, in which the court held that units of local government lacked authority to enter into collective bargaining agreements. ${ }^{28}$ At issue before the court was whether the authority to recognize unions and bargain collectively with them was implied in a county's and a school district's express authority to manage their jurisdictions' affairs and make contracts for services. ${ }^{29}$ In addressing this question, the court characterized the collective bargaining process as in tension with democratic principles. ${ }^{30}$

[T]here can be no question that the two boards involved in this case, by their policies and agreements, not only have seriously restricted the rights of individual employees to be heard but also have granted to labor unions a substantial voice in the boards' ultimate right of decision in important matters affecting both the public employer-employee relationship and the public duties imposed by law upon the boards. $^{31}$

As developed in Part III, the view that public sector collective bargaining is antidemocratic also affects interpretation of public sector labor relations acts in states that have enacted them.

26. Exec. Order 13,203, 3 C.F.R. 761 (2002), reprinted as amended in 5 U.S.C. $\S 7101$ (Supp. 2001).

27. See Clyde W. Summers, Public Employee Bargaining: A Political Perspective, 83 YALE L.J. 1156, 1159-61 (1974).

28. 232 S.E.2d 30 (Va. 1977).

29. Id. at 32 .

30. Id. at 39 .

31. Id. For a history of the treatment of public sector collective bargaining in Virginia, see Ann C. Hodges, Lessons from the Laboratory: The Polar Opposites on the Public Sector Labor Law Spectrum, 18 CORNELL J.L. \& PUB. POL'Y (forthcoming July 2009). 


\section{The ARgument that Public Sector Collective Barganing IMPEDES EFFECTIVE GOVERNMENT}

The primary issue that delayed the creation of the Department of Homeland Security as a cabinet level department was the fate of collective bargaining rights for employees of agencies that were to be merged into the new department. Among others, Senator Phil Gramm expressed the view that collective bargaining was inconsistent with national security in the post $9 / 11$ environment, asking rhetorically, "Do we really want some work rule negotiated prior to $9 / 11$ to prevent us from finding somebody who is carrying a bomb on a plane with your momma?"32 Similarly, in defending the decision of Admiral James Loy, the head of the Transportation Security Administration (TSA), to ban collective bargaining by TSA airport screeners, a TSA spokesperson declared, "When it comes to responding to new intelligence or terrorist threats on a moment's notice, we don't have time to check with a shop steward."33

The argument that collective bargaining would impede national security was a specific application of a general view that public employee collective bargaining impedes effective government. For example, in editorializing against collective bargaining rights for airport screeners, MSNBC commentator Tucker Carlson generalized against public employee unions' affect on government operations:

But we do know there are many people [who] would like to bring about another 9/11. So what are we doing about it? ... Democrats argue that TSA employees have a right to collective bargaining, and maybe they do. OK. But that is not the question. The question is will unionized screeners make air travel safer? Let's see. Have teachers' unions made the schools better? Have government employee unions improved [the] service at the DMV? As the head of the TSA explained to the Senate this week, a unionized work force at the airport will have a quote, "serious negative security impact." Well, that's it. That's all you need to know about this question. ${ }^{34}$

The view that collective bargaining impedes effective government can be traced back at least to the infamous Boston police strike of 1919. In August 1919, the AFLCIO chartered the Boston Policeman's Union. Boston police officers organized largely because their wages had stagnated, despite a high rate of inflation induced by World War I, and because they were forced to work extremely long shifts and to stay overnight in unhealthy, decrepit police stations. The Boston Police Commissioner responded by prohibiting officers from being members in the union or any other organization apart from veterans' groups. The commissioner suspended nineteen officers for their membership in the union, resulting in a walkout by three-fourths of the officers on September 9, 1919. For two days, law and order broke down with looting and rioting in downtown Boston and South Boston. Massachusetts Governor

32. 148 CONG. REC. 17,030 (2002).

33. Joseph Slater, Homeland Security vs. Workers' Rights? What the Federal Government Should Learn from History and Experience, and Why, 6 U. PA. J. LAB. \& EMP. L. 295, 315 (2004) (quoting Robert Johnson).

34. Tucker Carlson \& Willie Geist, TUCKER 1800 Hour for March 7, 2007, MSNBC NEWs, Mar. 7, 2007, available at 2007 WLNR 4345635. 
Calvin Coolidge called out the National Guard, which restored order. All of the strikers were fired. ${ }^{35}$

The specter of the Boston police strike has hung over public employee collective bargaining ever since. It led numerous courts to uphold public employer prohibitions against union membership despite union disavowal of strikes and disavowal of seeking traditional forms of collective bargaining. ${ }^{36}$ As late as 1963, the Michigan Supreme Court upheld the City of Muskegon's prohibition on police officer membership in labor unions. ${ }^{37}$ The city justified the prohibition on the ground that union membership was inconsistent with fulfilling the duties of a police officer:
A police officer is required by law and invariably becomes a neutralizer in controversies involving the right of public assemblage, neighborhood disputes, domestic difficulties and strikes, between labor and management. Again, his actions in these instances must be governed by his oath of office. He must recognize certain rights of people among which is the right of collective bargaining on the part of labor. Yet, at the same time, he must protect the rights and the property of management. In this instance, again, his neutrality must be the watchword of his every activity in the effort to protect the life and property of all those involved and to preserve peace and order during periods of such difficulty. ${ }^{38}$

More recently, the specter of the Boston police strike arose to strip certain federal employees of their rights to organize and bargain collectively. On January 7, 2002, President George W. Bush issued Executive Order 13,252, which, on national security grounds, prohibited collective bargaining by employees in five subdivisions of the Department of Justice: U.S. Attorneys' offices, Criminal Division, INTERPOL-U.S. National Central Bureau, National Drug Intelligence Center, and Office of Intelligence Policy and Review. ${ }^{39}$ Even though it is a felony for a federal employee to engage in a strike, ${ }^{40}$ White House spokesman Ari Fleischer defended the executive order saying, "There is a long tradition that presidents of both parties have honored about protecting the public by not allowing certain law enforcement or intelligence officials to strike."41

At a more general level, Professor Leo Troy has argued that public employee collective bargaining inherently impedes effective government and leads to municipal and school district bankruptcies. ${ }^{42} \mathrm{He}$ attributes this to the political nature of public sector collective bargaining and the conflict of interest that public officials face in

35. JosePh E. SLATER, Public WORKERS: GOVERNMENT EMPLOYEE UNIONS, THE LAW AND THE STATE, 1900-1962, at 11-38 (2004).

36. See Slater, supra note 8, at 1010-13.

37. See Local 201, Am. Fed'n of State, County and Mun. Employees v. City of Muskegon, 120 N.W.2d 197 (Mich. 1963).

38. Id. at 199.

39. Exec. Order No. 13,252, 3 C.F.R. 195 (2003), reprinted in 5 U.S.C. $\S 7103$ (2006).

40. 18 U.S.C. § 1918(3) (2006).

41. Joseph R. Grodin, June M. Weisberger \& Martin H. Malin, Public Sector EMPlOYMENT: CASES AND MATERIALS 14 (2004) (quoting White House spokesman Ari Fleischer).

42. Leo Troy, Are Municipal Collective Bargaining and Municipal Governance Compatible?, 5 U. PA. J. LAB. \& EMP. L. 453 (2003). 
having to manage their units of government while being dependent on the very unions with whom they negotiate for support when they seek reelection. ${ }^{43}$

A full airing of the debate over whether public employee collective bargaining impedes effective government has occurred in the ongoing debate over collective bargaining rights for airport screeners employed by the TSA. In response to the September 11, 2001, terrorist attacks, Congress enacted the Aviation and Transportation Security Act, ${ }^{44}$ which federalized airport screeners. Section 111(d) authorized the Under Secretary of Transportation for Security to fix the terms and conditions of security screeners "notwithstanding any other provision of law." January 8, 2003, the Under Secretary issued a memorandum stating that for purposes of national security, airport screeners would not be allowed to be represented by a labor union or engage in collective bargaining. As a consequence, the Federal Labor Relations Authority dismissed representation petitions filed by the American Federation of Government Employees (AFGE) seeking elections to determine whether the employees desired representation by AFGE. ${ }^{46}$

In the 2006 elections, Democrats gained a majority in the Senate and the House of Representatives. In 2007, House and Senate Democrats inserted into the bill implementing the recommendations of the $9 / 11$ Study Commission, a provision that would have restored collective bargaining rights to TSA employees. ${ }^{47}$ That touched off fierce opposition from the Bush Administration and its supporters.

A key theme of the opposition to collective bargaining rights for airport screeners was the asserted incompatibility between collective bargaining and the flexibility needed to ensure national security. For example, TSA Assistant Secretary Kip Hawley noted that after the British bombing plot was uncovered in August 2006, screening procedures were adjusted nationwide to deter liquid explosives and were implemented within twelve hours without creating significant flight delays. He argued that TSA required flexibility for responding rapidly to changing security issues and urged Congress to reject collective bargaining rights for airport screeners because it would inhibit such flexibility. ${ }^{48}$ The Office of Management and Budget echoed these concerns: "This flexibility is key to how DHS, through TSA, protects Americans while they travel, both at home and abroad. These provisions, by eliminating these authorities, would significantly diminish the Department's ability to respond quickly to security threats and would ultimately reduce transportation security.,"99

43. Id.; see also Terry M. Moe, The Union Label and the Ballot Box, EDUC. NExT, Summer 2006 , at 59 .

44. Aviation and Transportation Security Act, Pub. L. No. 107-71, 115 Stat. 597 (2001).

45. Id.; 49 U.S.C. $\S 44935$ (e)(2) (Supp. 2002).

46. See Dep't of Homeland Sec., Border \& Transport. Sec. Directorate, Transp. Sec. Admin., 59 F.L.R.A. 423 (2003).

47. Improving America's Security Act of 2007, S. 4, 110th Cong. (2007); H.R. 1, 110th Cong. (2007).

48. Kip Hawley, Assistant Sec'y, Transp. Sec. Admin., Statement Before the Subcommittee on Homeland Security, Committee on Appropriations, U.S. House of Representatives (Feb. 13, 2007), available at $\mathrm{http}: / / \mathrm{www} . t s a . g o v / a s s e t s / p d f / 10-16-07$ Testimony_HHS-TSIP_Hawley.pdf [hereinafter Hawley Statement].

49. Office of Mgmt. \& Budget, Exec. Office of the President, Statement of ADMINISTRATIVE POL'Y 2 (2007). 
Chief among the concerns voiced against collective bargaining was its impact on deployment of personnel. Assistant Secretary Hawley criticized the proposal to give airport screeners collective bargaining rights as "threaten[ing] to tie TSA's hands in deploying [personnel] to respond to changing threats ...."50 The Office of Management and Budget noted that TSA's response to the British bombing plot and to Hurricane Katrina was facilitated by its ability to change employees' duties and work locations quickly. ${ }^{51}$ A Heritage Foundation Web Memo echoed these concerns, arguing that "TSA ... needs the ability to rush screeners to high-risk locations and modify screening procedures at a moment's notice."

Opponents of collective bargaining by airport screeners argued that the need to negotiate the impact and implementation of management decisions would interfere with necessary deployment of personnel. For example, the Heritage Foundation cited an arbitration award which held that the Customs and Border Patrol (CBP) was obligated to negotiate with the National Treasury Employees Union, the exclusive representative of CBP employees, before reassigning personnel from the Port of Houston to Bush International Airport and the Port of New Orleans. ${ }^{53}$ The Senate Republican Policy Committee added that "if TSA were required to negotiate with multiple unions for every change in circumstance, it would take away from the agency's ability to rapidly respond to threat information." 54 In the House, Representative Pete Sessions was more blunt, asserting that "[c]ollective bargaining would have prevented implementing fluid operations for protecting our country by requiring TSA management to consult with union bosses before making critical homeland security decisions." 55

Opponents of collective bargaining for airport screeners also cited likely work rules that unions would negotiate which would impair the ability to respond to security threats. Senator Jim DeMint of South Carolina led the opposition in the Senate, arguing that "[c]ollective bargaining will tie TSA's hands with needless red-tape and create a homeland security disaster." 56 The Senate Republican Policy Committee contrasted TSA screeners without collective bargaining to Canadian screeners who have collective bargaining. ${ }^{57}$ It noted that as part of a labor dispute over Thanksgiving 2006, screeners at Toronto's Pearson International Airport engaged in a work-to-rule

50. Hawley Statement, supra note 48.

51. OFFICE OF MGMT. \& BUDGET, supra note 49 , at 2.

52. James Sherk, Collective Bargaining for Airport Screeners Is Unnecessary and Badfor National Security, No. 1372, THE HeRITAGE Foundation, Feb. 26, 2007, http://www.heritage.org/Research/HomelandSecurity/wm1372.cfm.

53. Id.

54. S. Republican Policy Comm., Providing Collective Bargaining Rights to TSA EMPLOYEES UNDERMINES NATIONAL SECURITY 2 (2007), available at http://rpc.senate.gov/public/_files/022807TSABargainingRightsDB.pdf.

55. 153 CONG. REC. H8790 (daily ed. July 27, 2007) (statement of Rep. Sessions).

56. Press Release, Senator Jim DeMint, Senate Democrats Vote to Weaken Homeland Security (Mar. 6, 2007), available at http://demint.senate.gov/public/index.cfm?FuseAction=PressReleases.Detail\&PressRelease $\mathrm{id}=\mathrm{d} 12 \mathrm{c} 82 \mathrm{~b} 5-159 \mathrm{~b}-48 \mathrm{bb}-90 \mathrm{a3}-6 \mathrm{a} 2 \mathrm{c} 1 \mathrm{e} 17 \mathrm{c} 8 \mathrm{a} 5 \&$ Month=3\&Year=2007\& Type=PressRelease.

57. S. REPUBLICAN POLICY COMM., supra note 54 , at 1-2. 
campaign which caused long lines and the rushing through of 250,000 passengers with little or no screening. ${ }^{58}$

Opponents of collective bargaining by airport screeners also cited the impact of negotiated seniority provisions as inconsistent with national security. The Heritage Foundation argued that seniority rules would result from collective bargaining and would harm national security by precluding TSA's ability to assign the best screeners to the most sensitive jobs and would inhibit TSA's ability to keep screeners motivated. ${ }^{59}$ Similarly, the Senate Republican Policy Committee warned:

The agency's personnel system is based on performance, not seniority, and is designed to reward "the best and the brightest." It is based on technical competence, readiness for duty and operational performance. It continually trains and upgrades the skills of its officers, making them available for higher pay and advancement along the way. Yet collective bargaining could curtail opportunities for advancement as training would all have to be negotiated with unions, even when the employees request training. Under collective bargaining, training could be subject to negotiation on need, design, order of training delivered, timeline, and method of delivery. ${ }^{60}$

Supporters of collective bargaining rights urged that union representation would give employees voice and improve worker moral, leading to reduced attrition. However, they did not address the specific arguments of opponents beyond contending that TSA had all the flexibility it needed because the Federal Service Labor Relations Statute allows agencies to take all necessary action to carry out their missions during emergencies. ${ }^{61}$

In public education, critics blame teacher unions for shortcomings in education quality, citing allegedly excessive teacher salaries and benefits, work rules that preclude flexibility necessary for school improvement, salary grids that preclude incentives for excellent performance and allocation of resources to recruit in areas of scarcity such as mathematics and science, and union defense of allegedly misfeasant and malfeasant teachers who ought to be terminated. In other words, as two critics put it, "collective bargaining is taking public education in an unsustainable direction,"62 with teacher unions as guardians of a failed status quo.

The salary grid is one of the aspects of teacher collective bargaining agreements that opponents frequently attack. The typical salary grid determines teacher pay based on level of education and years of service. One editorial writer voiced a common criticism, complaining that "[a]greements typically require that the worst teachers be

58. Id.

59. See Sherk, supra note 52.

60. S. RePUBliCAN POLICY COMM., supra note 54, at 3.

61. See, e.g., 153 CONG. REC. E1729 (daily ed. July 27, 2007) (statement of Rep. Thompson); Letter from Bennie G. Thompson, Chairman, U.S. House of Representatives, Comm. on Homeland Sec., to Michael Chertoff, Sec'y of Homeland Sec. (Mar. 1, 2007), available at

$\mathrm{http} / /$ homeland.house.gov/press/index.asp?ID=183\&SubSection=0\&Issue=0\&DocumentTyp $\mathrm{e}=0$ \&PublishDate $=$.

62. Howard Fuller \& George A. Mitchell, A Culture of Complaint, EDUC. NEXT, Summer 2006 , at 18,18 . 
paid the same as the best (since pay differentials are based on credentials and experience, not merit)." 63 The salary schedule has also been criticized for rewarding graduate degrees without evidence that they improve teacher effectiveness and for placing an inordinate amount of salary reward toward the end of the teacher's career instead of at the beginning when the teacher makes the most progress in development. ${ }^{64}$ This inefficient distribution of rewards is said to contribute to the problem of significant attrition in the teacher ranks in the first years of a teacher's career. ${ }^{65}$ The uniform salary schedule also is criticized for making it difficult to recruit teachers in areas of scarcity, such as math and science. ${ }^{66}$

Other criticisms of collective bargaining in public education are comparable to the criticism that collective bargaining inhibits needed flexibility in national security. Critics decry transfer rights under collective bargaining agreements that limit administrators' ability to fill vacancies with the best qualified person ${ }^{67}$ They also decry the difficulties involved in terminating ineffective, incompetent, or misbehaving teachers. ${ }^{68}$ And, they attack the plethora of collectively negotiated work rules. As one observer noted:

Collective bargaining agreements are often the scar tissue of the struggle between the parties' attempts to limit the arbitrary discretion of the other side. Flip through a thick contract and you'll see many examples of attempts to define transfer rights and time use. Managers want to impose rules on the behavior of teachers while maintaining maximum flexibility in deploying them as an asset. Unions want to limit the arbitrary discretion of management. Each parry and thrust becomes restrictive contract language that defines in minute detail the limits of each party's discretion until the document itself is an embodiment of the sclerosis of the relationship. ${ }^{69}$

Examples cited include the Milwaukee Public Schools, where critics contend the parties are governed by a "232-page contract with more than 2,000 additional

63. Paul E. Peterson, Let the Public in: How Closed Negotiations with Unions Are Hurting Our Schools, EdUC. NEXT, Summer 2006, at 5, 5; see also MARK J. HolleY \& PATRICK J. Wright, Mackinac Center Policy Brief: A Merrt-PAy Pilot Program for Michigan PUBLIC SCHOOLS, No. S2008-7, at 1 (2008) (opining that salary grid does not encourage teachers to improve student performance but instead encourages them to spend nights and weekends studying for advanced degrees that will not increase their effectiveness); Maya Kremen, Tenure Helps Good Teachers and Shelters the Bad Ones, THE RECORD, July 19, 2006 (contrasting a teacher cited for failing to monitor and supervise her classroom who was making $\$ 86,350$ per year with the teacher voted best teacher at North Bergen (N.J.) High School who was making $\$ 47,550$ per year and complaining that " $[t]$ eachers are paid based on how long they"ve been around, not how well they perform").

64. See Jacob Vigdor, \$crap the \$acrosanct \$alary \$chedule: How About More Pay for New Teachers, Less for Older Ones, EDuc. NEXT, Fall 2008, at 37.

65. See id. Interestingly, Professor Vigdor's analysis focused on teacher salary schedules in North Carolina which cannot be the product of collective bargaining because that state prohibits collective bargaining by units of local government.

66. See Eva Moscowitz, Breakdown, EDUC. NEXT, Summer 2006, at 24, 25.

67. See id.

68. See, e.g., id.; Kremen, supra note 63; Peterson, supra note 63.

69. Linda Kaboolian, Table Talk, EDUC. NEXT, Summer 2006, at 14, 16. 
supporting documents," resulting in "[a]n endless debate about what is and is not allowed in the daily governance of the school system and the creation of an environment where the interests of students are routinely subordinated to those of adult teachers. $" 70$ The documents, according to critics, preclude principals from requiring teachers to submit lesson plans periodically, limit the amount of time teachers can be required to attend meetings, and prevent principals from requiring teachers to attend meetings before or after school to write goals and objectives. ${ }^{71}$ Critics also point to New York City, where a contract of more than 200 pages, coupled with side agreements and state laws, "determine nearly every aspect of what a teacher does, and does not do . . . and what can and can't be done to them," including limiting their teaching to 3.75 hours per day and precluding requiring teachers to supervise lunchroom or study hall, help special-education students off buses, write truant slips, help college applicants prepare transcripts, and score city-wide tests. ${ }^{72}$

Some advocates of charter schools view them as one method of freeing public education from the allegedly obstructionist and counterproductive activities of teacher unions. ${ }^{73}$ As Paul Hill and his colleagues observed, "Charter school leaders equate the [union] vision of professionalism with resistance to change and protection of unfit teachers."74

The 1990s saw a significant amount of backlash against teacher collective bargaining. In Ohio, the legislature reacted to perceived inefficiencies in state university professors' workload by prohibiting bargaining on that subject. ${ }^{75}$ In 1994 , Michigan prohibited bargaining on the identity of a school district's group insurance carrier, the starting day of the school term and the amount of required pupil contact time, composition of site-based decision-making bodies, decisions whether to provide

70. Fuller \& Mitchell, supra note 62, at 20; see also Howard L. Fuller, George A. Mitchell \& Michael E. Hartmann, Collective Bargaining in Milwaukee Public Schools, in CoNfLICTING Missions? TEACHERS UNIONS AND EdUCATIONAL ReForm 110 (Tom Loveless ed., 2000) [hereinafter CONFLICTING Missions].

71. See Fuller \& Mitchell, supra note 62, at 20.

72. Moskowitz, supra note 66, at 25.

73. See Leo Casey, Who's Afraid of Teacher Voice? Charter Schools and Union Organizing, EDwIZE, Nov. 17, 2005, http://edwize.org/whos-afraid-of-teacher-voice-charterschools-and-union-organizing (quoting Norman Atkins of Uncommon Schools stating "[G]ood charter schools organize themselves in ways that keep unions out"); Matt Cox, Children vs. Unions, NAT'L ReV. ONLINE, Sept. 17, 2003, $\mathrm{http} / / / \mathrm{www}$. nationalreview.com/comment/comment-cox091703.asp ("Despite their rhetoric, teacher unions place power and money above the welfare of students. They are part of a reactionary establishment that sees the schools as a giant sinecure rather than something that exists to benefit children. Battling well-heeled unions every time a charter school opens is no boon to reformers or the kids they want to help."); see also David W. Kirkpatrick, Viewpoint: Organizing Charter Schools, a Challenge to Unions, THE BUCKEYE INST. FOR PUB. POL'Y SOLUTIONS, June 5, 2006, http://www.buckeyeinstitute.org/article/690.

74. PaUl T. Hill, Lydia Rainey \& ANDREW J. Rotherham, THE Future of Charter SCHOOLS AND TEACHER UNIONS: RESULTS OF A SYMPOSIUM 5 (2006), available at http://www.ncsrp.org/downloads/charter_unions.pdf.

75. See Cent. State Univ. v. Am. Ass'n of Univ. Professors, 526 U.S. 124 (1999) (upholding the constitutionality of the statute codified at OHIO REV. CODE ANN. $\$ 3345.45$ (West 2008)). 
interdistrict or intradistrict open enrollment opportunities, the decision to operate a charter school, the decision to contract out noninstructional support services, the decision to use volunteers for any services, and decisions to use instructional technology on a pilot basis. ${ }^{76}$ Most of these subjects had been held to be mandatory subjects of bargaining by the Michigan courts and the Michigan Employment Relations Commission. $^{77}$

Contemporary media commentary suggests that the act was a backlash aimed primarily at the Michigan Education Association (MEA). ${ }^{78}$ In urging support for the bill, the Grand Rapids Press editorialized:

[The MEA's] longstanding stranglehold on the bargaining process has given Michigan teachers a Rolls-Royce health-insurance plan, some of the highest school salaries in the country and virtual immunity from the state law forbidding public employee strikes. A consequence is that Michigan school costs from 1980 through ' 92 rose an average of 8.1 percent a year, with the difference being passed along to citizens in their property-tax bills. ${ }^{79}$

It applauded that under the act "school boards could no longer be bullied into buying the insurance through the MEA's subsidiary." subjects of bargaining was to prevent ensuing disputes from creating an impasse in negotiations. ${ }^{81}$

This law was one of several actions portrayed as necessary to reduce the power of the MEA. Republican John Engler defeated incumbent Democrat James Blanchard in the 1990 gubernatorial election and attained reelection in 1994, in part by demonizing the MEA. ${ }^{82}$ During Engler's tenure, the state abolished property taxes as a source of school funding, prohibited local districts from raising additional revenue through millages, and tied state funding to the number of students, while providing for large numbers of charter schools and allowing students to attend districts other than those of their residences. ${ }^{83}$ In signing the elimination of property tax-based funding, Governor Engler declared the end of "the power and control the teacher unions have had over education policies in Michigan ...., ${ }^{, 84}$ Backlash continued in 1996 as Michigan

76. Мich. Comp. Laws $\S 423.215$ (3) (2008).

77. See Andrew Nickelhoff, Marching Headlong into the Past: 1994 PA 112 and the Erosion of School Employee Bargaining Rights, 74 MicH. B.J. 1186, 1188 (1995).

78. See, e.g., John Foren, Engler-GOP Drive to Cut School Costs Aims at MEA. They Want to Cut Bargaining Power and Rein in Teacher Strikes, GRAND RAPIDS PRESS, Mar. 19, 1994, at Al.

79. Editorial, Senate's Turn on School Costs: House-Passed Bill Shifts Control from MEA to Taxpayers, Boards, GRAND RAPIDS PRESS, Apr. 19, 1994, at A8.

80. Id.

81. See Michael Matheson, Note, Have Michigan Public School Teachers Lost Their Ability to Strike Under 1994 PA 112?, 75 U. DET. MERCY L. REV. 415, 430 (1998).

82. See William Lowe Boyd, David N. Plank \& Gary Sykes, Teacher Unions in Hard Times, in CONFLICTING MISSIONS, supra note 70, at 174, 176-77.

83. See id. at 178-79.

84. Id. at 179. 
revised its school code, increasing the mandatory school year from 180 instructional days to 190 with no provision for increased teacher compensation. ${ }^{85}$

Around the same time, legislative backlash against teacher bargaining also arose in Oregon. The Oregon Court of Appeals held that class size was a mandatory subject of bargaining. ${ }^{86}$ A few years later, the legislature amended the Oregon statute to exclude from mandatory subjects of bargaining:

[C]lass size, the school or educational calendar, standards of performance or criteria for evaluation of teachers, the school curriculum, reasonable dress, grooming and at-work personal conduct requirements respecting smoking, gum chewing and similar matters of personal conduct, the standards and procedures for student discipline, the time between student classes, the selection, agendas and decisions of 21 st Century Schools Councils .... ${ }^{87}$

In Illinois, where strikes by public employees other than law enforcement personnel and firefighters are lawful, the 1995 Chicago School Reform Act prohibited strikes against the Chicago Public Schools and the City Colleges of Chicago for a specified period of time. ${ }^{88}$ The statute also prohibited decision and impact bargaining on the following subjects: charter school proposals and leaves of absence to work for a charter school, subcontracting, layoffs and reductions in force, class size, class staffing and assignment, class schedules, academic calendar, hours and places of instruction, pupil assessment policies, use and staffing of pilot programs, and use of technology and staffing to provide technology. ${ }^{89}$ Contemporary media accounts suggest that the restrictions on bargaining were aimed at the Chicago Teachers Union. ${ }^{90}$ In 2003, after Democrats were elected to majorities in both houses of the legislature and after a Democrat was elected governor, the Chicago School Reform Act was amended to make these subjects permissive subjects of bargaining. ${ }^{91}$

Similar school reform legislation in Pennsylvania limited collective bargaining rights. Under Act 46, enacted in 1998, whenever the Philadelphia school system is found to be in financial distress, bargaining may not be required over subcontracting, reductions in force, staffing patterns, assignments, class schedules, school calendar,

85. See id. at 181 .

86. Tualatin Valley Bargaining Council v. Tigard Sch. Dist. 23J, 808 P.2d 101 (Or. Ct. App. 1991), rev'd and remanded, 840 P.2d 657 (Or. 1992).

87. OR. REV. STAT. § 243.650(7)(e) (2005). In contrast to Michigan, the Oregon legislative changes resulted from negotiations between the state's Democrat governor and Republicancontrolled legislature. The original bill restricted the scope of bargaining more severely. For a fascinating description of the process, see Henry H. Drummonds, $A$ Case Study of the Ex Ante Veto Negotiations Process: The Derfler-Bryant Act and the 1995 Amendments to the Oregon Public Employee Collective Bargaining Law, 32 WILLAMETTE L. REV. 69 (1996).

88. Ill. Pub. Act 89-15, $\S 10$ (codified at 115 ILL. Comp. StaT. ANN. 5/13(a) (West 2006) (effective May 30, 1995)).

89. Ill. Pub. Act $89-15, \S 10$ (codified at 115 Ill. Comp. STAT. ANN. 5/4.5 (West 2006) (effective May 30, 1995)).

90. See, e.g., Doug Finke \& Amy E. Williams, GOP Plan for Chicago Schools Takes Aim at Union, STATE JOURNAL-REGISTER, May 11, 1995, at 1.

91. Ill. Pub. Act 93-3 $\S 10$ (codified at 115 Ill. Comp. Stat. ANN. 5/4.5 (West 2006) (effective Apr. 16, 2003)). 
pupil assessment, teacher preparation time, experimental programs, charter schools, and use of technology. ${ }^{92}$

The view that collective bargaining impedes effective government and the accompanying backlash has not been limited to national security and public education. For example, in revoking the executive order which had conferred bargaining rights on Indiana state employees, Governor Mitch Daniels cited provisions in the state employees' collective bargaining agreement which required thirty days' notice before reorganizing departments, which he contended would preclude him from transferring workers to newly created agencies. ${ }^{93} \mathrm{He}$ also maintained that the state paid for thousands of hours spent on union-related activities instead of public service. ${ }^{94}$

\section{The Paradox In Public Sector Labor LaW Doctrine}

The view that public sector collective bargaining is antidemocratic is not confined to those who advocate prohibiting unionization of public employees. Wellington and Winter, for example, cite their concerns with the antidemocratic nature of public sector collective bargaining as grounds for prohibiting public employee strikes, ${ }^{95}$ and for limiting the scope of issues subject to negotiation. ${ }^{96}$ Similarly, Clyde Summers, a staunch supporter of public sector collective bargaining, urges that its antidemocratic nature drives the determination of which subjects are mandatorily bargainable. ${ }^{97}$

These views have not been lost on the courts. Courts have cited the antidemocratic nature of public sector collective bargaining as a primary justification for limiting the subjects over which public employers are required to negotiate. The South Dakota Supreme Court's decision in Aberdeen Education Association v. Aberdeen Board of Education, ${ }^{98}$ provides an extreme example. The court expressed concern that collective negotiations not impinge on the ability of "the whole people [to] speak by means of laws enacted by their representatives" 99 and held a number of items, including teacher preparation periods, the scheduling of teacher conferences, and the availability of aides to perform nonteaching duties such as playground supervision, to be outside the scope of bargainable subjects. ${ }^{100}$

92. See David J. Strom \& Stephanie S. Baxter, From the Statehouse to the Schoolhouse: How Legislatures and Courts Shaped Labor Relations for Public Education Employees During the Last Decade, 30 J.L. \& EDUC. 275, 295 (2001); see also Boyd et al., supra note 82, at 18692 (describing political backlash against teacher unions in Pennsylvania, particularly Philadelphia).

93. See Clarren, supra note 4.

94. Id.

95. See Wellington \& WINTER, supra note 14 , at 142.

96. See id. at 167.

97. See Clyde Summers, Public Sector Bargaining: A Different Animal, 5 U. PA. J. LAB.\& EMP. L. 441 (2003).

98. 215 N.W.2d 837 (S.D. 1974).

99. Id. at 841 .

100. Id. 
Similarly, the Maryland Court of Appeals has held that school calendar and employee reclassifications are prohibited subjects of bargaining. ${ }^{101}$ The court explained:

Local [school] boards are state agencies, and, as such, are responsible to other appropriate state officials and to the public at large. Unlike private sector employers, local boards must respond to the community's needs. Public school employees are but one of many groups in the community attempting to shape educational policy by exerting influence on local boards. To the extent that school employees can force boards to submit matters of educational policy to an arbitrator, the employees can distort the democratic process by increasing their influence at the expense of these other groups. ${ }^{102}$

Jurisdictions have adopted a variety of approaches to curbing the antidemocratic nature of public sector collective bargaining. A few specify in the statute what subjects must be negotiated. ${ }^{103}$ Most follow the National Labor Relations Act model and require bargaining on wages, hours, and other terms and conditions of employment, but temper that mandate with broadly worded management rights clauses. ${ }^{104}$ States such as New Jersey and South Dakota go so far as to prohibit bargaining on subjects not deemed mandatorily negotiable. ${ }^{105}$ Their rationale is rooted in the view that public sector bargaining is antidemocratic. As the New Jersey Supreme Court asserted, "the very foundation of representative democracy would be endangered if decisions on significant matters of governmental policy were left to the process of collective negotiation, where citizen participation is precluded."106

Most jurisdictions follow the private sector model of dividing subjects of bargaining into mandatory, permissive, and prohibited. The problem that labor boards and courts have had to confront is how to deal with two potentially extremely broad concepts. At some level, every decision affects conditions of employment, and, at some level, every decision affects public policy or managerial authority. Even bargaining about such basic matters as wages affects the allocation of scarce public resources and thereby affects the determination of public policy. The Court of Appeals of Maryland aptly described the situation: "[V]irtually every managerial decision in some way relates to 'salaries, wages, hours, and other working conditions,' and is therefore arguably negotiable. At the same time, virtually every such decision also involves educational policy considerations and is therefore arguably nonnegotiable." 107

101. Montgomery County Educ. Ass'n v. Bd. of Educ., 534 A.2d 980, 988-89 (Md. 1987).

102. Id. at 987 (citation omitted); see also Appeal of City of Concord, 651 A.2d 944, 946 (N.H. 1994) (expressing similar concerns); City of Brookfield v. Wisconsin Employment Relations Comm'n, 275 N.W.2d 723 (Wis. 1979) (expressing similar concerns).

103. See, e.g., IOWA CODE ANN. $\S 20.9$ (West 2001); KAN. STAT. ANN. $\$ 75-4327$ (b) (1997).

104. See GRODIN ET AL., supra note 41, at 213-20.

105. See Local 195, IFPTE v. State, 443 A.2d 187 (N.J. 1982); Aberdeen Educ. Ass'n v. Aberdeen Bd. of Educ., 215 N.W.2d 837 (S.D. 1974).

106. Ridgefield Park Educ. Ass'n v. Ridgefield Park Bd. of Educ., 393 A.2d 278, 287 (N.J. 1978); see also Local 195, 443 A.2d at 191 ("Matters of public policy are properly decided, not by negotiation and arbitration, but by the political process.").

107. Montgomery County Educ. Ass'n, 534 A.2d at 986. 
The most common response to this problem has been to balance the interests of employees in bargaining an issue against the impact of the issue on managerial prerogatives and public policy. This balancing test has taken various forms.

One form of the balancing test is, in effect, a presumption against collective bargaining. For example, in Corpus Christi Fire Fighters Association v. City of Corpus Christi, the Court of Appeals of Texas held that bargaining is required on a subject "only if it has a greater effect on working conditions than on management prerogatives." 108 The court held that grooming standards for firefighters and changes to rules governing the evaluation of employees who drove city vehicles were not mandatorily bargainable. ${ }^{109}$

Similarly, the California Supreme Court, in holding that the decision to eliminate a bargaining unit position and reassign its duties was a mandatory subject of bargaining, opined, "If an action is taken pursuant to a fundamental managerial or policy decision, it is within the scope of representation only if the employer's need for unencumbered decisionmaking in managing its operations is outweighed by the benefit to employeremployee relations of bargaining about the action in question." 110 In Pennsylvania, the presence of an express management rights provision has been determinative in setting presumptions. The general Pennsylvania public employee labor relations statute contains an express management rights provision. ${ }^{111}$ This has led the Pennsylvania Supreme Court to hold that a subject is mandatorily bargainable if "the impact of the issue on the interest of the employe [sic] in wages, hours and terms and conditions of employment outweighs its probable effect on the basic policy of the system as a whole."112 On the other hand, the Pennsylvania statute governing police and firefighter collective bargaining does not contain a management rights provision ${ }^{113}$ and Pennsylvania courts have interpreted it to require bargaining unless "the managerial policy ... substantially outweigh[s] any impact an issue will have on the performance of the duties of the police or fire employees." 114

Most jurisdictions, however, have not expressly declared a presumption in favor of or against bargaining. Instead, they have opined that whether an item is a mandatory subject of bargaining will turn on whether its impact on working conditions or its impact on public policy predominates. ${ }^{115}$ These jurisdictions candidly confess that such subject-by-subject balancing does not lend itself to predictability or consistency. ${ }^{116}$

108. 10 S.W.3d 723, 728 (Tex. App. 1999).

109. Id.

110. Bldg. Material \& Constr. Teamsters' Union v. Farrell, 715 P.2d 648, 653 (Cal. 1986).

111. 43 PA. STAT. ANN. $§ 1101.702$ (West 2008).

112. Pa. Labor Relations Bd. v. State Coll. Area Sch. Dist., 337 A.2d 262, 268 (Pa. 1975).

113. 43 Pa. Stat. ANN. $§ 217.1$ (West 2008).

114. Fraternal Order of Police, Lodge No. 5 v. Pa. Labor Relations Bd., 727 A.2d 1187, 1190 (Pa. Commw. Ct. 1999).

115. See, e.g., W. Hartford Educ. Ass'n v. DeCourcy, 295 A.2d 526, 531 (Conn. 1972); Fraternal Order of Police, Miami Lodge No. 20 v. City of Miami, 609 So. 2d 31, 33-34 (Fla. 1992); Montgomery County Educ. Ass'n v. Bd. of Educ., 534 A.2d 980, 986 (Md. 1987); City of Lynn v. Labor Relations Comm'n, 681 N.E.2d 1234, 1238 (Mass. App. Ct. 1997); Springfield Educ. Ass'n v. Springfield Sch. Dist. No. 19, 621 P.2d 547, 559-60 (Or. 1980); W. Bend Educ. Ass'n v. Wis. Employment Relations Comm'n, 357 N.W.2d 534, 538 (Wis. 1984).

116. See, e.g., City of Lynn, 681 N.E.2d at 1237 (stating that "[a]ny attempt to define with 
Typically, the courts leave such determinations to the labor relations board to make in the first instance. ${ }^{117}$ Nevertheless, the approach of subject-by-subject balancing has encouraged parties to fight over the negotiability of subjects long settled as mandatorily bargainable in the private sector. For example, although the Supreme Court held in 1979 that prices charged in an employee cafeteria are a mandatory subject of bargaining, ${ }^{118}$ almost three decades later, the University of Illinois and unions representing its employees fought over whether parking fees charged to employees had to be bargained. ${ }^{119}$

A survey of the results of such ad hoc balancing across jurisdictions makes it clear that whether a subject primarily affects working conditions or managerial policy is in the eyes of whoever is reading the scale. Conflicting results have been reached on numerous subjects including: class size, ${ }^{120}$ school calendar, ${ }^{121}$ drug testing, ${ }^{122}$

precision and certainty the subjects about which bargaining is mandated ... is doomed to failure ..."). Not every jurisdiction has adopted this approach. One notable exception is Montana. In Bonner School District No. 14 v. Bonner Education Ass'n, the court held that teacher transfers were a mandatory subject of bargaining even though the Montana Collective Bargaining for Public Employees Act's management rights provision included as management prerogatives to "hire, promote, transfer, assign, and retain employees." 176 P.3d 262, 267 (Mont. 2008). The court reasoned that mandating bargaining did not conflict with the statutory managerial prerogative because bargaining did not require agreement and the school board retained the exclusive right to make the final decision on the matter. Id. at 268. Similarly, under the Vermont State Employees Labor Relations Act, bargaining is required on "[a]11 matters relating to the relationship between the employer and employees ... except those matters which are prescribed or controlled by statute." VT. STAT. ANN. tit. 3, $\S 904$ (2003). In Vermont State Colleges Faculty Federation v. Vermont State Colleges, the Vermont Supreme Court rejected the Vermont Labor Relations Board's analogy to precedent under the NLRA dividing subjects of bargaining into mandatory and permissive categories. 418 A.2d 34, 37 (Vt. 1980). The court interpreted the Vermont statute as dividing subjects into those that relate to the relationship between employer and employee and those that are prescribed or controlled by statute. Id. at 38. The court held that a union proposal for a system of shared faculty governance was mandatorily bargainable. Id.

117. See, e.g., Central City Educ. Ass'n v. Ill. Educ. Labor Relations Bd., 599 N.E.2d 892, 904 (Ill. 1992).

118. Ford Motor Co. v. NLRB, 441 U.S. 488, 494-503 (1979).

119. Bd. of Trustees of Univ. of Ill. v. Ill. Educ. Labor Relations Bd., 862 N.E.2d 944 (Ill. 2007).

120. Compare W. Hartford Educ. Ass'n v. DeCourcy, 295 A.2d 526, 536-37 (Conn. 1972), and Boston Teachers Union, Local 66 v. Sch. Comm., 350 N.E.2d 707, 713-14 (Mass. 1976), with Hillsborough Classroom Teachers Ass'n v. Sch. Bd., 423 So. 2d 969, 969 (Fla. Dist. Ct. App. 1982), Nat'l Educ. Ass'n-Topeka v. Unified Sch. Dist. 501, 592 P.2d 93, 98 (Kan. 1979), City of Biddeford v. Biddeford Teachers Ass'n, 304 A.2d 387, 403 (Me. 1973), Sch. Dist. of Seward Educ. Ass'n v. Sch. Dist., 199 N.W.2d 752, 759 (Neb. 1972), Dunellen Bd. of Educ. v. Dunellen Educ. Ass'n, 311 A.2d 737, 741 (N.J. 1973), and W. Irondequoit Teachers Ass'n v. Helsby, 315 N.E.2d 775 (N.Y. 1974).

121. Compare State v. Conn. Bd. of Labor Relations, No. 379709S, 1993 WL 7261, at *6 (Conn. Super. Ct. Jan. 8, 1993), with Montgomery County Educ. Ass'n v. Bd. of Educ., 534 A.2d 980, 980 (Md. 1987).

122. Compare Holiday v. City of Modesto, 280 Cal. Rptr. 206, 206 (Cal. Ct. App. 1991), and County of Cook v. Licensed Practical Nurses Ass'n, 671 N.E.2d 787, 792-93 (Ill. App. Ct. 1996), with Fraternal Order of Police, Miami Lodge 20 v. City of Miami, 609 So. 2d 31, 31 (Fla. 1992). 
smoking, ${ }^{123}$ and subcontracting. ${ }^{124}$ The same observer of the scale has drawn fine lines between mandatory and nonmandatory subjects. For example, the California Court of Appeals held that drug testing of a firefighter was a mandatory subject of bargaining, but suggested that the balance between employer prerogative and employee interests would be struck differently upon a showing that the order to drug test was motivated primarily by concerns of public safety. ${ }^{125}$ The Florida Supreme Court held that a city need not negotiate drug testing of police officers where there is reason to suspect drug involvement, but suggested that a general random drug testing program would require bargaining. ${ }^{126}$

In New York, the employer's motivation also is significant in determining whether a subject must be bargained. In Levitt v. Board of Collective Bargaining, ${ }^{127}$ the City of New York unilaterally instituted a requirement that all applicants for employment and for promotion disclose any debts they owed to the city and either pay those debts or agree to have payments deducted from their wages as a condition of employment or promotion. ${ }^{128}$ The court held that the directive was a mandatory subject of bargaining because its primary motive was to raise revenue. ${ }^{129}$ The court suggested that if the directive had been concerned with reputation and character as a qualification for employment or promotion, bargaining would not have been required. ${ }^{130}$

Legal hair splitting is also quite evident in Oregon. The Oregon Court of Appeals has held that firefighter manning is not a mandatory subject of bargaining but the number of firefighters who will respond to a fire call is mandatorily negotiable. ${ }^{131}$ Teachers in Oregon fare no better than firefighters in seeking certainty regarding what they have a right to negotiate. The Oregon court has distinguished between the length of the school day, which it views as a nonnegotiable matter of educational policy, and the number of teacher-student contact hours, which must be negotiated. ${ }^{132}$ It also has distinguished between the school calendar, which need not be negotiated, and vacation periods and the definition of work year for salary purposes, for which bargaining is required. ${ }^{133}$ Similarly, the Minnesota Court of Appeals has ruled that the establishment of a ride-along policy in which college student interns and Explorer scouts accompany

123. Compare Newark Valley Cent. Sch. Dist. v. Public Emp. Relations Bd., 632 N.E.2d 443, 444 (N.Y. 1994), with Local 1186 of Council No. 4 v. State Bd. of Labor Relations, 620 A.2d 766 (Conn. 1993).

124. Compare In re Hillsboro-Deering Sch. Dist., 737 A.2d 1098 (N.H. 1999), with Amalgamated Transit Union, Local 1593 v. Hillsborough Area Reg'l Transit Auth., 742 So. 2d 380, 380 (Fla. Dist. Ct. App. 1999), City of Belvidere v. Ill. State Labor Relations Bd., 692 N.E.2d 295, 305 (Ill. 1998), and In re Local 195, 443 A.2d 187, 194 (N.J. 1982).

125. Holiday, 280 Cal. Rptr. at 212-13.

126. Fraternal Order of Police, Miami Lodge 20,609 So. 2d at 35.

127. 589 N.E.2d 1 (N.Y. 1992).

128. Id. at 2 .

129. Id. at 5 .

130. Id.

131. Int'l Ass'n of Firefighters, Local 314 v. City of Salem, 684 P.2d 605, 608 (Or. Ct. App. 1984).

132. Gresham Grade Teachers Ass'n v. Gresham Grade Sch. Dist. No. 4, 630 P.2d 1304 (Or. Ct. App. 1981).

133. E. County Bargaining Council v. Centennial Sch. Dist., 685 P.2d 452, 453 (Or. Ct. App. 1984). 
police officers in their squad cars is not a mandatory subject of bargaining, but such decisions as the shifts on which they ride and procedures for handling emergencies are. $^{134}$

The consequences of such case-by-case, jurisdiction-by-jurisdiction application of the balancing test, particularly when combined with the fine splitting of hairs apparent in some jurisdictions, has produced a surreal type of legal realist approach to the scope of bargaining in the public sector. Under this approach, there are no settled rules of general applicability which guide the parties' conduct. Instead, the law becomes what the labor board or court declares it to be in any particular case and the precedential effects of the declaration beyond the particular case are minimal. This approach encourages litigation over bargaining rights and managerial prerogatives and discourages cooperative discussion of issues of mutual concern.

The stakes are high over whether a matter is considered a mandatory subject of bargaining. If a matter is not mandatorily negotiable, the union is cut out completely. For example, the employer has no obligation to provide the union with information relevant to a nonmandatory subject of bargaining. ${ }^{135}$ Similarly, if a matter is not a mandatory subject, the employer may bypass the union completely and pick and choose individual employees from whom to seek input. ${ }^{136}$

Concern that public employee collective bargaining is antidemocratic excludes unions from negotiation over any issue that a labor board or court deems a matter of public policy. It channels unions to negotiate only over those issues where the direct effects on wages and working conditions (i.e. traditional bread and butter issues) outweigh the effects on public policy. Where unions gain the right to negotiate issues that significantly affect public policy, they do so by stressing the bread and butter nature of the issue, even though the union's motivation may be to serve as a voice for the employees in the making of the policy. For example, a police union gains the right to negotiate over drug testing by emphasizing drug testing as an issue of employee discipline. Yet the union may be seeking a voice for police officers in the setting of policy on drug testing in light of the effects of drug testing on officer morale, the ability of citizens to exploit the policy to harass innocent officers with fraudulent complaints, and the need to effectively root out impaired officers whose presence endangers not only public safety but the safety of fellow officers. ${ }^{137}$ Similarly, a teacher's union gains the right to negotiate class size by portraying it as an issue of employee workload, even though its motive may be to serve as a vehicle for teacher voice in the educational policy concerns involved in setting class size. ${ }^{138}$

Channeling collective bargaining away from subjects that involve issues of policy and confining it to traditional bread and butter issues relegates unions to negotiating

134. City of W. St. Paul v. Law Enforcement Labor Servs., Inc., 466 N.W.2d 27, 28 (Minn. Ct. App. 1991).

135. See, e.g., Vill. of Franklin Park v. Ill. State Labor Relations Bd., 638 N.E.2d 1144, 1148 (Ill. App. Ct. 1994).

136. See, e.g., Corpus Christi Fire Fighters Ass'n v. City of Corpus Christi, 10 S.W.3d 723, 728 (Tex. App. 1999).

137. See Fraternal Order of Police, Miami Lodge $20 \mathrm{v}$. City of Miami, 609 So.2d 31, 35 (Fla. 1992) (involving a dispute over the need for bargaining in establishing drug-testing policies for police officers).

138. See, e.g., W. Hartford Educ. Ass'n v. DeCourcy, 295 A.2d 526, 536-37 (Conn. 1972). 
provisions in collective bargaining agreements that protect their members against the risks of the enterprise engendered by decisions made and imposed unilaterally by management. This is particularly evident in the distinction between decision bargaining and impact bargaining. Yet, it is the requirement of impact bargaining that led critics of collective bargaining rights for airport screeners to decry collective bargaining as inconsistent with the flexibility that TSA needed to protect our national security. ${ }^{139}$

Absolved of any responsibility for the decisions themselves by their exclusion from having any voice, unions have done a very effective job of insulating their members from the risks of the decisions. They have done such a good job, that the fruits of their negotiations may be viewed in some cases as impeding effective government. For example, in public education, teacher unions negotiated provisions defining reasonable expectations for their work as protection against arbitrary decisions made by management. As one urban principal explained, "“[t]he thickness, the scope of this phone book of a contract is, in my view, an indictment of how administrators ran their schools in the past. ${ }^{, " 140}$ However, unions have done such a successful job of protecting the workers they represent that they have impeded effective government. Susan Moore Johnson and Susan Kardos explain:

[I]t seemed sensible not to require teachers to teach subjects for which they had no preparation or to use time designated for classroom preparation standing on bathroom duty. It was only fair to guarantee teachers a half-hour of duty-free time to eat their lunch. It did not seem sensible, though, that teachers' work time could be prescribed to the minute or that they might be expected to meet with parents only twice a year. Often contracts, particularly those in large, urban districts, defined teachers' responsibilities narrowly and minimally, thus making teaching more like labor and less like a profession. ${ }^{141}$

Concerns that mandating bargaining will be antidemocratic-which leads to the exclusion of workers, through their unions, from having an institutional voice in the decision-making process-absolve unions of any responsibility for the decisions themselves. This frees them to concentrate, in impact bargaining, on insulating the employees to the maximum extent possible from the risks posed by the decisions, even to the point of undermining the reasons for the decisions. For example, in response to the publication of $A$ Nation at Risk, ${ }^{142}$ numerous state legislatures crafted reforms. In California, unions negotiated the implementation of the state's Mentor Teacher Program in ways that preserved deference to seniority and spread the benefits as broadly as possible. ${ }^{143}$ More generally, unions reacted to legislatively-imposed reforms by undermining the state policies in impact bargaining. ${ }^{144}$

139. See supra text accompanying notes 53-55.

140. Susan Moore Johnson \& Susan M. Kardos, Reform Bargaining and Its Promise for School Improvement, in CoNFLICTING Missions, supra note 70, at 7, 12.

141. Id. at 13.

142. NAT'L COMM'N ON EXCELLENCE IN EDUC., A NATION AT RISK: ThE IMPERATIVE FOR EDUCATIONAL REFORM (1983).

143. See Johnson \& Kardos, supra note 140, at 23.

144. Id. at 24. 
Consider, more recently, Racine Education Association v. Wisconsin Employment Relations Commission, ${ }^{145}$ where the court upheld a decision by the Wisconsin Employment Relations Commission that the Racine Unified School District's decision to implement a pilot program with a year-round school calendar was not a mandatory subject of bargaining. ${ }^{146}$ The conclusion that the decision to move to a year-round calendar was a matter of educational policy had the result of cutting out the representative of the school district's teachers from participation in the decision concerning what would best improve the delivery of educational services. Rather than being invited to invest in the risks of the school district's enterprises by giving the union a seat at the table in discussions over scheduling, the union was presented with a fait accompli. Although I do not know what specifically occurred in Racine's impact bargaining, it would not be surprising in such a situation to find the union insisting on strict adherence to the seniority provisions of the collective bargaining agreement, which could result in an overrepresentation or underrepresentation of less experienced teachers on the year-round schedule. Similarly, it would not be surprising to see the union insisting in negotiations on additional compensation for teachers moving to a year-round schedule or for expanded teacher personal days or other benefits that could be used to not only lessen the burden on the teachers of the schedule change, but also to impede the effectiveness of the schedule change for the students. It is also not surprising, given the case-by-case ad hoc balancing used to determine whether a matter is mandatorily negotiable, that the union litigated the legality of the school district's unilateral move to a year-round schedule. Such litigation could only cloud the program with uncertainty until the litigation was concluded.

\section{A WAY OUT OF THE PARADOX}

The paradox of public sector labor law is that to avoid antidemocratic aspects of public sector collective bargaining, the law has channeled public employee unions away from investing in the risks of the public enterprise and toward insulating their members from those risks. Unions have done such an effective job in their channeled role that their collective bargaining agreements can impede effective government.

There is good reason to believe that giving employees, through their unions, an institutional voice in the initial decision making will increase the likelihood that they will become agents of, instead of obstructions to, effective change. Studies in the private sector show that when unions are strong and have a cooperative relationship with management, they provide independent employee voice that plays a crucial role in the successful development and sustenance of high performance workplace practices. ${ }^{147}$ These findings are consistent with the general social-psychology procedural justice literature which finds positive outcomes associated generally with

145. 571 N.W.2d 887 (Wis. Ct. App. 1997).

146. Id. at 887.

147. See Carol Gill, Union Impact on the Effective Adoption of High Performance Work Practices, 19 Hum. ReSOURCE MGMT. Rev. 39 (2009); see also William N. Cooke, Product Quality Improvement Through Employee Participation: The Effects of Union-Management Administration, 46 INDUS. \& LAB. REL. REv. 119 (1992) (finding positive collective employee voice and product quality improvement when unions are treated as partners and union leaders are involved in administering participation programs). 
employee voice, that is, having an opportunity to be heard concerning decisions that affect them, even when the outcomes are not what the employees desired. ${ }^{148}$

Experiences in the public sector suggest similar positive results from an institutionalized employee collective voice in the decision-making process. Consider the complaint that unions impede reform in public education by clinging to the salary grid, which bases teachers' pay exclusively on education level and years of service. ${ }^{149}$ When movement away from the salary grid is imposed unilaterally, union resistance is almost reflexive. For example, when the New York public schools announced a pilot program to estimate the value added to student test performance by teachers in 140 schools, union president Randi Weingarten responded that the union would "fight this on all grounds-educational, legal and moral."

Contrast the reaction in New York to the union's engagement in Denver, Colorado. In 2004, the membership of the Denver Classroom Teachers Association (DCTA) voted to approve a union-school district incentive pay plan known as the Professional Compensation System for Teachers (Pro Comp). ${ }^{151}$ A design team consisting of five teachers, five administrators, and two citizens devised the plan. ${ }^{152}$ In November 2005, voters approved a tax increase to fund the plan. ${ }^{153}$ New hires are automatically enrolled in the plan, while existing teachers have the option of enrolling. ${ }^{154}$ Although the DCTA cautioned many existing teachers about opting into Pro Comp, ${ }^{155}$ twenty-eight percent opted in during the program's first year. ${ }^{156}$ Under the plan, teachers receive compensation based on "professional development units" representing specific knowledge and skills they acquire (as opposed to any college-education school credits) according to the results of their professional evaluations, as an incentive to teach in hard-to-staff schools and in hard-to-find specialties, and according to student achievement. ${ }^{157}$ A council composed of teachers, administrators, and community members run the professional evaluation program. ${ }^{158}$

148. See, e.g., Brian D. Cawley, Lisa M. Keeping \& Paul E. Levy, Participation in the Performance Appraisal Process and Employee Reactions: A Meta-Analytic Review of Field Investigations, 83 J. APPLIED PSYCHOL. 615 (1998).

149. See supra text accompanying notes 63-66.

150. See Jane Hannaway \& Andrew J. Rotherham, Collective Bargaining in Education and Pay for Performance 11 (Nat'l Ctr. on Performance Incentives, Working Paper 2008-11, 2008) available at

www.performanceincentives.org/data/files/directory/ConferencePapersNews/Hannaway_et_a 1_2008.pdf.

151. Denver Public Schools, Professional Compensation for Teachers, Overview, available at http://denverprocomp.dpsk12.org/stories/storyReader $\$ 27$.

152. Id.

153. See Bess Keller, Denver Voters Pave Way for Incentive Pay, EDUC. WEEK, Nov. 9, 2005 , at 3,18 .

154. Id.

155. See Denver Classroom Teachers Assoclation, Straight Talk About ProComp 3 (2006), available at http://ritter.tea.state.tx.us/opge/disc/gov_edexcellence/StraightTalk_ProComp.pdf(cautioning teachers between steps 5 and 13 on the traditional salary schedule against opting in).

156. Hannaway \& Rotherham, supra note 150 , at 18.

157. See Keller supra note 153 .

158. Agreement Between School District No. 1 in the City and County of Denver, 
Pro Comp's biggest labor-management challenge occurred in the spring and summer of 2008. The union sought an across-the-board percentage pay raise, while the district sought to shift incentives to increase compensation for junior teachers, with increases to base pay, other than cost of living increases, stopping after thirteen years of service. ${ }^{159}$ Performance-based bonuses for senior teachers would continue but would not be folded into base salary. ${ }^{160}$ The controversy led to a union vote of no confidence in the superintendent and a sick-out in May 2008. ${ }^{161}$ Opposition to the district's proposal was not unanimous within the union, however, as a significant number of teachers signed a petition affirming principles that tended to support the district's proposals. ${ }^{162}$ Ultimately, an agreement was reached which increased available incentives, boosted starting teacher pay to the level the district had sought, and capped increases in base pay except for cost-of-living increases for teachers after fourteen years of service. ${ }^{163}$

Public sector collective bargaining is said to impede effective government by making it difficult, if not impossible, to terminate ineffective employees. Where management controls the evaluation and discipline of employees, the union is channeled into a role of protecting its members from management-imposed discipline. It protects its members collectively by negotiating controls over the implementation of management's unilaterally promulgated performance standards. These controls often include specifying the number of times a principal may observe a teacher, requiring advance notice of observations, and similar protections for teachers under review. It protects its members individually by challenging management to justify disciplinary measures in an adversarial proceeding, such as an arbitration or statutory tenure or civil service proceeding.

When the union serves as a vehicle for collective employee voice in the evaluation and discipline of employees, the union can be transformed from an impediment to effective government into a contributor. Such has been the case with teacher peer review. One of the earliest and most notable examples of teacher peer review was in the Toledo, Ohio Public Schools. ${ }^{164}$ The Toledo system employs an Internal Board of Review (IBR), consisting of five union and four district representatives. New teachers participate in a two-year intern program with an IBR consulting teacher. The IBR also oversees a plan for tenured teachers whose substandard performance led to a joint referral by the teacher's principal and union building representative. Evidence suggests

State of Colorado and Denver Classroom Teachers association: Professional COMPENSATION SYSTEM FOR TEACHERS 5 (2006), available at http://www.dpsk12.org/manila/programs/denverprocomp/ProCompAgreementrev12008.pdf.

159. See Kathleen Kingsbury, A Merit-Pay Standoff in Denver, TIME, Aug. 19, 2008, available at http://www.time.com/time/nation/article/0,8599,1833989,00.html.

160. See id.; Jeremy P. Meyer, Merit Pay Splits DPS, Union, DENVER POST, Aug. 11, 2008, at A1; Stephanie Simon, Denver Teachers Object to Changes in Pay-for-Performance Plan, WALl ST. J., Aug. 18, 2008, at A3.

161. See Kingsbury, supra note 159.

162. See Denver Teachers for Change.org, Sign Our Petition, http://denverteachersforchange.org//?page=Sign-Our-Petition.

163. See Editorial, DPS Deal Would Be Good for District and Teachers, DENVER POST, Aug. 26, 2008, at A18.

164. This discussion of peer review is drawn from my earlier article, Martin H. Malin \& Charles Taylor Kerchner, Charter Schools and Collective Bargaining: Compatible Marriage or Illegitimate Relationship?, 30 HARV. J. L. \& PUB. POL'Y 885, 904-07 (2007). 
that more probationary teachers and tenured teachers with performance problems leave the system than under a system of review and discipline unilaterally controlled by management. A similar system in the Cincinnati, Ohio Public Schools was examined by the Secretary of Labor's Task Force on Excellence in State and Local Government Through Labor-Management Cooperation and found to have led to a greater percentage of probationary teachers and teachers in remediation leaving the system when reviewed by peers than when reviewed solely by administrators. ${ }^{165}$

Peer review has been successful in large part because of teacher involvement through their unions in developing the evaluation standards. Teachers are forced to reflect on what constitutes good teaching and express those standards in terms that are accessible and acceptable to their peers. Having actively participated in developing the standards, the union is more likely to view its role as protecting the standards of teaching instead of protecting individual teachers from evaluations unilaterally imposed from above. Peer reviewers spend considerably greater time than administrators with the teachers under review, and when reviews are negative, they generally produce a record that is very compelling. Although the teachers remain contractually or statutorily entitled to union representation to challenge negative results, the thoroughness of the peer review record makes it unlikely that such challenges will succeed. ${ }^{166}$

Contracting out is often put forth as a panacea for remedying public employee collective bargaining's impediments to effective government. Some jurisdictions further this alternative by holding that the decision to subcontract is not a mandatory subject of bargaining. ${ }^{167}$ However, although the decision may not be mandatorily negotiable, the employer generally remains obligated to bargain the impact of the decision on the employees. In such impact bargaining, the union may seek to raise the transaction costs of contracting to such a level as will induce the employer to abandon the option.

An alternative to public employers avoiding collectively represented employees by contracting their jobs to the private sector is to empower those workers to compete against private contractors for the work. One example of such empowerment, highlighted by the Secretary of Labor's Task Force, occurred in the Massachusetts Highway Department. When the state decided to subcontract highway maintenance, the unions who represented the employees who had been performing those duties formed a coalition and bid against the contractors. ${ }^{168}$ They were awarded the job and assumed responsibility for organizing and managing it. ${ }^{169}$ The resulting improvements included a sixty percent reduction in workers' compensation claims, a seventy percent reduction in overtime and a $49.5 \%$ reduction in sick time. ${ }^{170}$ Improved efficiency saved the state

165. U.S. SEC'y OF LABOR's TASK ForCe ON EXCELLENCE IN STATE AND LOCAL GOV'T Through Labor-Mgmt. CoOperation, Working TOGETHER for Public SERVICE: Final REPORT 117-18 (1996) [hereinafter U.S. SEC'Y OF LABOR'S TASK FORCE].

166. See Charles Taylor Kerchner \& Julia E. Koppich, Organizing Around Quality: The Frontiers of Teacher Unionism, in CONFLICTING Missions, supra note 70, at 281, $290-93$.

167. See, e.g., Amalgamated Transit Union, Local 1593 v. Hillsborough Area Reg'l Transit Auth., 742 So. 2d 380 (Fla. Dist. Ct. App. 1999).

168. U.S. SEC'Y OF LABOR'S TASK FORCE, supra note 165, at 27.

169. Id.

170. $I d$. 
more than $\$ 7.8$ million. ${ }^{171}$ Road sweeping and cleaning of gutters became more regular. ${ }^{172}$ Worker suggestions for improved maintenance of equipment enabled the purchase and lease of new equipment. ${ }^{173}$ As with teacher peer review, the role of the union changed dramatically. The Secretary of Labor's Task Force quoted one union official involved, "My job used to be to go around and ask people what grievances they had. My job is now to go around asking people what ideas they have to improve this job."."174

Perhaps the largest effort to benefit from expanded employee voice in the public sector occurred with the Clinton Administration's establishment of labor-management partnerships. In the final days of the Clinton Administration, the Office of Personnel Management issued a report, which, among other things, catalogued the successes produced by labor-management partnerships. ${ }^{175}$ Specific examples listed in the report included:

- Partnering between the Internal Revenue Service and the National Treasury Employees Union to modernize and restructure the IRS, resulting in measurable improvements in customer service and job satisfaction.

- A partnership between American Federation of Government Employees Local 3973 and Defense Contract Management Command's Raytheon Missile Systems facility resulted in an overwhelming improvement in customer service ratings as workload increased $100 \%$ and the workforce downsized, with $\$ 900,000$ saved from the reduction in labor-management litigation.

- The U.S. Mint and the AFGE Mint Council engaged in joint strategic planning, resulting in the U.S. Mint's consistent ranking near the top of the American Customer Satisfaction Index and its production of record numbers of coins and return of record profits to taxpayers.

- The Social Security Administration (SSA) and the AFGE partnership reengineered practices related to SSA's toll free number, resulting in SSA outscoring all other organizations for 800 number customer satisfaction in 1995 and in a 1999 customer satisfaction rating of eighty-eight percent.

- Partnerships between the James A. Haley Veterans' Hospital and the AFGE Local 547, the Florida Nurses Association, and the Tampa Professional Nurses Unit reduced delivery time for critical medication from ninety-two minutes to twenty minutes, cut turnaround time for $\mathrm{x}$-ray reports from eight days to one day, and reduced processing time for pension and compensation exams from thirty-one days to eighteen days.

171. Id.

172. Id.

173. Id. at 27-28.

174. Id. at 84 . For a discussion of a similar initiative in Indianapolis, see Stephen Goldsmith \& Mark E. Schneider, Partnering for Public Value: New Approaches in Public Employee Labor-Management Relations, 5 U. PA. J. LAB. \& EMP. L. 415 (2003).

175. U.S. OfFice OF PERS. MgMt., LABOR-MANAGEMENT PARTNERSHIP: A REPORT TO THE PRESIDENT (2000), available at http://www.opm.gov/lmr/report/. Specifically, Section III, Results and Accomplishments, discusses many of these examples. Id. 
- A National Treasury Employees Union and Customs Service partnership designed a seven-step strategy to increase seizures of illegal drugs. During the six-month life of the joint action plan, narcotics seizures increased by forty-two percent and drug currency seizures increased by seventy-four percent.

- A partnership between the Defense Distribution Depot in San Joaquin and AFGE Local 1546 saved $\$ 950,000$ per year by reducing workplace accidents by twenty percent and ergonomic injuries by forty percent, reduced overtime expenses from $\$ 9.8$ million to $\$ 1.4$ million, and reduced production costs from $\$ 25.42$ per unit to $\$ 23.48$ per unit.

Charles Kerchner and I have catalogued additional examples of teacher unions investing in and sharing the risks of the public school enterprise. ${ }^{176}$ The Secretary of Labor's Task Force catalogued numerous others in the public sector generally. ${ }^{177}$ These examples demonstrate that when employees, acting through their exclusive bargaining representative, have a voice in decisions that affect the risks of the enterprise, they tend to share in the risks and to be transformed into agents of positive change. ${ }^{178}$ These examples share another characteristic. They all occurred in spite of the law rather than because of the law.

Although it has become a cliché to speak of the states as laboratories for experimentation in different areas of legal regulation, the cliché applies with considerable force to collective representation of public employees. ${ }^{179}$ The states, and the federal government with respect to its own employees, have experimented with a diversity of approaches to such matters including collective bargaining rights for supervisors, ${ }^{180}$ the regulation of strikes, ${ }^{181}$ and the development of alternative approaches to resolving bargaining impasses. ${ }^{182}$ More recently, some public sector jurisdictions have experimented with mandating card check recognition. ${ }^{183}$

Public sector jurisdictions in these areas and others have shown a willingness to break away from strict adherence to the NLRA model. A similar break with the NLRA model, whereby a subject is either mandatorily bargainable or subject to complete unilateral control by management, may produce fruitful reform. This reform may be able to solve the paradox that currently exists in public sector labor relations whereby concerns with the antidemocratic tendencies of public employee collective bargaining lead to a narrowing of the scope of bargaining which channels employees and their

176. Malin \& Kerchner, supra note 164, at 903-11.

177. U.S. SEC'Y OF LABOR'S TASK FORCE, supra note 165.

178. This does not mean that employees do or should take on all risks. Protection against some of the risks of the enterprise can play an essential role in transforming employees into agents of positive change. See, e.g., Goldsmith \& Schneider, supra note 174, at 422.

179. See generally Hodges, supra note 31 (comparing two very different state approaches to public employee collective bargaining, Illinois and Virginia, and discerning "lessons from the laboratory").

180. See GrodIN ET AL., supra note 41, at 140-52.

181. See id. at 277-325.

182. See id. at 326-70.

183. See Raja Raghunath, Stacking the Deck: Privileging "Employer Free Choice" Over Industrial Democracy in the Card-Check Debate, 87 NEB. L. REV. 329, 344-51 (2008). 
unions into becoming vehicles that impede effective government rather than facilitating it.

There are numerous approaches that jurisdictions might consider for enhancing collective employee voice in an institutionalized way. Jurisdictions might experiment with broadening the scope of traditional bargaining. Montana may be headed in this direction. In Bonner School District No. 14 v. Bonner Education Association, the Montana Supreme Court held that teacher transfers were a mandatory bargaining subject, even though the Montana Collective Bargaining for Public Employees Act expressly included transferring employees as a management prerogative. ${ }^{184}$ The court reasoned that mandating bargaining did not conflict with the statutory managerial prerogative because bargaining did not require agreement and the school board retained the exclusive right to make the final decision on the matter. ${ }^{185}$ The court could reach that conclusion because under the Montana statute, a union can compel an employer to participate in nonbinding fact finding, ${ }^{186}$ but interest arbitration may occur only by agreement. ${ }^{187}$ Thus, the employer in Montana does retain the exclusive right to make the final decision even if the matter is a mandatory subject of bargaining.

The evolving law in Montana suggests a second approach to employee voice in decisions affecting the risks of the enterprise for jurisdictions to consider. They might make such decisions mandatory subjects of bargaining for purposes of negotiations but permissive subjects for purposes of strikes, in right to strike jurisdictions, ${ }^{188}$ and interest arbitration in jurisdictions that mandate arbitration as their impasse resolution procedure. Thus, a union would not have a right to strike over the subject and would not be able to compel arbitration over it. Yet, because the decision would be a mandatory subject for purposes of negotiation, the employer would be precluded from bypassing the exclusive representative and would be under a duty to supply relevant information to that representative.

Alternative models for consideration exist. These include the labor-management partnerships established under the Clinton Administration. The structure of those partnerships evolved during President Clinton's two terms in office. Initially, they consisted of representatives of the employer and the union, but they evolved to include representatives of middle-level managers.

Another model has emerged for some employees in Minnesota. Minnesota requires that employers meet and confer with representatives of their professional employees to discuss policies and other matters relating to employment that are not mandatory subjects of bargaining. ${ }^{189}$ It requires that the meet-and-confer sessions take place at

184. 176 P.3d 262 (Mont. 2008).

185. Id. at 268 .

186. MONT. CODE ANN. § 39-31-309(3) (2007).

187. Id. § 39-31-310.

188. I recognize that in Montana, most public employees have a right to strike. See MoNT. CODE ANN. § 39-31-401 (2007) (prohibiting strikes by police officers); id. $\S 39-34-105$ (prohibiting strikes by firefighters); $i d$. $\S 39-32-110$ (restricting strikes by health care employees); State v. Public Employee Craft Council, 529 P.2d 78 (Mont. 1974) (interpreting Montana public employee collective bargaining statute's right to engage in concerted activities for mutual aid and protection as including a right to strike).

189. MINN. STAT. ANN. § 179A.07(3) (West 2006). 
least once every four months. ${ }^{190}$ It also prohibits the employer from meeting and conferring with any employee or group of employees in a bargaining unit, except through their exclusive bargaining representative. ${ }^{191}$ The Supreme Court has upheld the constitutionality of this latter provision. ${ }^{192}$ Such meet-and-confer sessions can provide employees with a voice in decisions that are not mandatorily negotiable.

The experiences of employer's such as the City of Indianapolis and the Massachusetts Highway Department suggest that jurisdictions consider requiring public employers to afford unions the opportunity to bid and provide them with the information necessary to make informed bids, before contracting out bargaining unit work. In public education, some have suggested that teacher unions and school districts be required to negotiate student performance and accountability for the results. ${ }^{193}$ The above list is only a beginning.

A common characteristic of all of the above models is that they mandate collective employee voice without mandating all of the elements of formal collective bargaining. In particular, they do not subject the collective discussions to a final impasse procedure, whether it be a right to strike or a right to interest arbitration. When a union negotiates a mandatory subject of bargaining with a right to compel interest arbitration in the event of a bargaining impasse, the union has the ability to shut out other interest groups from the process that will make the decision with finality. When the union has the right to strike, some, such as Wellington and Winter, have argued that it possesses a weapon that is so powerful that it will effectively shut out other interest groups from the process. ${ }^{194}$ Elsewhere, I have disputed this latter point. ${ }^{195}$ I will not repeat the challenge here. The debate over the right to strike in public employment is irrelevant to the proposal advanced here, where no right to strike would attach. The key point is that mandating formal collective employee voice in the decision-making process does not exclude other interest groups from that process. Consequently, the concerns for democratic processes that have led to courts narrowing the scope of formal bargaining need not inhibit experimentation with alternative vehicles for collective employee voice.

Of course, as such examples as the Denver experiment with merit pay, teacher peer review in Toledo, and the Massachusetts Highway Authority illustrate, when people on both sides want to work together for their mutual benefit they will do so in spite of the law and will succeed. On the other hand, no matter what the legal structure, there will be parties who will seek to subvert its purposes. When the law is structured in a manner more favorable to collective employee voice in employer decision making, there will be managers who will not really provide voice to the union and there will be unions who will use the structure strategically to obstruct the government entity's mission. Most people, however, allow themselves to be channeled along the lines that the law channels them and thus, for most relationships, the legal structure will make a difference. Once jurisdictions break with the NLRA bipolar model that provides that

190. Id. § 179A.08(2).

191. Id. § 179A.07(4).

192. Minn. State Bd. for Cmty. Colls. v. Knight, 465 U.S. 271 (1984).

193. See, e.g., Kaboolian, supra note 69 , at 16.

194. WELLINGTON \& WINTER, supra note 14, at 25.

195. See Martin H. Malin, Public Employees' Right to Strike: Law and Experience, $26 \mathrm{U}$. MiCH. J.L. REFORM 313, 319-25 (1993). 
every matter is either mandatorily negotiable or left to unilateral management control, they can experiment with vehicles of enhanced employee voice which may solve the paradox in public sector labor law by preserving democratic processes while transforming the roles of exclusive bargaining representatives. 
